\title{
Vliv vybraných osobnostních korelátů na kreativitu v tanci u adolescentů
}

\section{The Influence of Personality and Cognitive Aspects on Creativity in Dance in Adolescents}

\author{
Lenka Kraváčková, Marie Blahutková
}

Fakulta sportovních studií Masarykovy univerzity, Brno

\begin{abstract}
Abstrakt
Cílem práce je ověrit vliv tance na kreativitu u vybrané skupiny adolescentů tancujících a adolescentů netancujících. Pro studii byl sestaven výbèr adolescentů tanečníků z folklórního souboru a výbèr adolescentů netanečníkì, u kterých jsme provedli Brace test a test pohybové kreativity. Prostřednictvím osobnostní ankety byla získána personální data o testovaných probandech. Za použití statistických metod jsme porovnali ziskaná data $z$ testů. V Brace testu vykazovala experimentální skupina lepši výsledky pouze na hladině věcné významnosti, $v$ testu pohybové kreativity nebyly také nalezeny statisticky významné rozdíly, byla prokázána pouze věcná významnost. $Z$ výsledků vyplývá, že vhodně vedená výuka tělesné výchovy na střední škole přispivá $k$ všestrannému pohybovému rozvoji adolescentů.
\end{abstract}

\begin{abstract}
The purpose of this research is to certify influence of dance on creativity of two chosen groups of adolescents - dancers and nondancers. For this study we compiled a selection of adolescent dancers from a folklore ensemble and adolescent nondancers. They were tested with Brace test and Creativity movement test. By means of personality enquiry we received personal data from the tested groups. Using statistical methods we compared the obtained data. In the Brace Test the experimental group showed a higher score only on the substantive significance level, whereas in the test of physical creativity no statistically significant differences were found. Only the substantive significance has been proved. The results indicate that a suitable physical education form at a secondary school contributes to an all-round development in adolescents.
\end{abstract}

Klíčová slova: $\quad$ adolescence, tanec, taneční umění, kreativita, kreativní tanec

Key words: $\quad$ adolescence, dance, dancing art, creativity, creative dance

\section{ÚVOD}

Proč se do popředí zájmů různých studií a výzkumů dostává právě tvořivost? Je zdrojem pokroku ve vědách, technice, umění a společnosti vůbec. Proto se stala předmětem intenzivního zájmu a je dnes pokládána za jednu z nejcennějších vlastností osobnosti. Zvláštní komplex schopností představuje tvořivost (kreativita). Kreativita je schopnost poznávat předměty v nových vztazích a originálním způsobem (originalita, nová kombinace), smysluplně je používat neobvyklým způsobem (flexibilita), vidět nové problémy tam, kde zdánlivě nejsou (senzitivita), odchylovat se od navyklých schémat myšlení a nepojímat nic jako pevné (proměnnost), vyvíjet z norem vyplývající ideje i proti odporu prostředí (nonkonformismus). Kreativita je schopnost nacházet něco nového, co představuje obohacení kultury a společnosti.

V období adolescence jsou na dospívající organismus kladeny vysoké nároky nejen $\mathrm{z}$ hlediska zvyšování duševní a tělesné zátěže, ale právě rozvoj kreativity v tomto období hraje velikou úlohu v budoucím životě mladého člověka. Trvalou charakteristikou adolescence zůstává, že je považována za most mezi dětstvím a dospělostí. $Z$ ontogenetického hlediska je jejím základním atributem dokončení pohlavního dozrávání, fyzický a duševní rozvoj (růst) a sociální učení v nejširším slova smyslu. Výrazněji se rozvíjejí základní schopnosti člověka jako symbolizace, anticipace, zástupné učení, sebereflexe a seberegulace. Zejména sebereflexe a seberegulace nabývají na významu a samy o sobě se stávají pro adolescenty vý- 
znamnou hodnotou (Macek, 1999). V adolescenci se mění povaha učení. Je to dáno jednak mentálními schopnostmi dospívajícího, jednak rozmanitostí a složitostí nových situací, do kterých se adolescent dostává. Nově se formuje schopnost odvozovat všechny možné kombinace konkrétních i abstraktních objektů, a také schopnost volit různé úhly pohledu na jevy v prŕítomnosti, minulosti i budoucnosti - to vše dává novou kvalitu i úvahám o sobě samém (Nakonečný, 1997). Tanec je možností, jak propojit rozvoj kreativity v dospívání a vhodně motivovat mládež k pohybovým činnostem.

Forma tance vzniká spojením jednotlivých pohybových motivů do celku. Nejjednodušší formy se vytvářejí stř́ídáním a opakováním pohybů a póz $\mathrm{v}$ určitém rytmickém a dynamickém uspořádání.

Taneční umění odkrývá duševní život člověka. Umělecká kvalita tanečních obrazů se určuje jejich obsahem a formou (Payneová, 1999, Petrová, 1999). Základní výrazové prostředky tance jsou harmonické pohyby a pózy měnící se a opakující se v prostoru a v čase podle určitých kompozičních principů, dynamika, rytmus, tempo. Od osmdesátých let se tanec chápe jako druh umění zasahující do výchovných a společenských souvislostí. Využívá se také ve skupinách se speciálními potřebami (např. u handicapovaných). Pokud chápeme tanec jako druh umění, je zapotřebí použít určitou specifickou taneční techniku (Morgenroth, 1987). Forma a technika vycházejí z nácviku, který specificky zapojuje tělo jako třeba v baletu, technice podle Limona nebo Grahamové (Cohen, 1966). Labanův prístup klade důraz na kreativní tanec, kdy se pohyb formuje sám ze sebe a vzájemným propojením vytvárí tanec. V této oblasti kreativního tance nás nejvíce zajímají pohybové vlastnosti nebo mezilidské vztahy, které se při takovéto tělesné aktivitě projevují. Při kreativním tanci si formu a styl určuje každý sám.

Tvořivost je velmi komplexní schopnost, v níž se vedle faktorů kognitivních uplatňují i faktory motivační a neintelektové rysy osobnosti. Podstatou tvořivosti je originalita. Protože tvořivost je zdrojem pokroku ve vědách, technice, umění a v životě společnosti vůbec, stala se předmětem intenzivního zájmu a je dnes pokládána za jednu z nejcennějších vlastností osobnosti. Pro komplexní povahu tvořivosti, která přesahuje oblast kognitivity, byl vytvořen pojem tvořivá osobnost, který vyjadřuje širší osobnostní souvislosti tvořivosti (Bean, 1995). Od romantického pojetí tvořivosti, omezeného obvykle na tvořivost uměleckou, jejíž zdroje byly hledány v nevědomí, se dospělo $\mathrm{k}$ psychometricky založenému zkoumání faktorů tvořivosti, jakož i k výchově a výcviku tvořivosti (Clegg, Birch, 2005). Podstatným znakem tvořivé osobnosti je autonomie a snaha po seberealizaci. Poukazuje to na určitou výlučnost tvořivých osobností, které lze ovšem najít nejen v umění a ve vědě, ale i v podnikání a dalších oblastech společenského života. Existují ovšem rozdíly v tvůrčích procesech různého druhu - uměleckém, vědeckém (Dočkal, 2005). S pojmem tvořivosti jsou spojovány i pojmy inspirace, intuice a zejména pojem divergentního myšlení (Gordonová, 2003). Existují také neintelektové faktory tvořivosti, které byly zjištovány výzkumem různých skupin tvořivých osobností (Carter, Russell, 2003). Psychologové např. zkoumali kategorie tvůrčích pracovníků, rozdíly mezi umělci a neumělci - umělci jsou např. více introvertní, agresivní a nonkonformističtí (Maisel, 2002). Zdá se, že existuje typ tvořivé osobnosti, tj. určitý syndrom rysů spojených s tvořivostí, daný především vysokou inteligencí, silnou motivací a nonkonformismem (Königová, 2007). K dalším patř́i výrazná emocionalita, esteticky akcentovaný vztah ke skutečnosti a šíře zájmů. K tomu přistupují faktory tvořivosti, ale uvedené souvislosti je nutno vysvětlit, a to se dosud nepodařilo.

Východisko pro vytvoření teorie tvořivé osobnosti zaujal S. Arieti (1976), který zdůrazňuje, že tvořivost je třeba odlišit od spontaneity a originality. Rozdíl mezi originalitou a kreativitou vystupuje zvláště ve snech: sny přicházejí spontánně a jsou často originální, nicméně nemohou být chápány jako produkt tvořivosti, jsou privátními zážitky a mají, až na nepatrné výjimky, hodnotu jen pro snícího. Kreativita je funkcí ega, dává životu a práci smysl, je zdrojem hlubokého uspokojení, a je tak i zdrojem pozitivního sebehodnocení (Dacey, Lennon, 2000). V kreativním procesu vystupují kombinace primárních a sekundárních procesů (první jsou funkcí pudů, druhé racionální mysli). Tuto kombinaci označuje Arieti jako terciární procesy a chápe je jako integraci archaických, pudově založených procesů s logickými a racionálními procesy, jako „magickou syntézu“, z níž se vynořuje nové, neočekávané a žádoucí. Podle Freudova pojetí vychází tvořivost ze sublimace sexuální energie v podmínkách frustrované sexuality. 
Kreativita má být jakousi náhradou sexuálního uspokojování, je ekvivalentní sexualitě. Avšak mnozí tvořiví lidé měli bohatý sexuální život. Na základě psychometrického př́stupu podal H. G. Gough (1964) přehled rysů tvořivé osobnosti (Carter, Russell, 2004):

1. Tvořivé myšlení je flexibilní myšlení.

2. Vnímání a asociace tvořivé osoby směřují k menší všeobecnosti a k menší typičnosti.

3. Tvořivý jedinec projevuje zájem o formu a eleganci, který ho vede $\mathrm{k}$ tomu, že není poután přesností a pečlivostí.

4. Tvořivá osobnost je intuitivní a empatická, je psychicky náladová, intraceptivní nebo má zájem o lidské jednání.

5. Tvořivá osobnost je spíše otevřená než usuzující, více vnímá, než usuzuje, a nachází zalíbení v nových prístupech.

6. Tvořivá osobnost je esteticky senzitivní.

7. Tvořivá osobnost je emocionálně a sociálně senzitivní.

8. Tvořivá osobnost je složitá osobnost.

Zvláštní téma představují psychické bariéry tvořivosti a jejich překonávání (Kirst, Diekmeyer, 2003). Zpracoval je podrobně J. L. Adams (1974), který klade důraz na nevědomé zdroje tvořivosti a soudí, že mnoho tvůrčích nápadů je potlačeno nebo „utlumeno“, protože je jejich nositelé nenechají v podvědomí dostatečně uzrát nebo protože ohrožují integritu ega. Proto je důležitou metodou uvolňování tvořivých sil nevědomí, resp. metoda „divokých myšlenek“ neboli metoda „mozkové bouře“ („brainstorming“), založená na stimulaci nápadů a současném vyloučení veškeré kritiky (Blahutková, Dvořáková, 2005). Psychické bariéry tvořivosti jsou analogické jevu fixace myšlení, neschopnosti odpoutat se od konvenčnosti, stereotypie apod. (Blahutková et al., 2005).

Cílem této práce je zjistit vliv tréninku na zvýšení kreativity v tanci. Pro studii byl sestaven výběr probandů, kteř́ začali tancovat bud' již jako děti od svých šesti let, anebo až na střední škole, tedy od patnácti let. Jako kontrolní skupina byla vybrána skupina probandů, kteří nikdy netancovali. U obou skupin jsme provedli Brace test a test pohybové kreativity. Prostřednictvím osobnostní ankety byla získána personální data o testovaných probandech. Za použití statistických metod jsme porovnali získaná data z testů.

\section{METODIKA}

\section{Výzkumný soubor}

Výzkumný soubor tvořilo třicet respondentů ve věku osmnáct až dvacet dva let. Skupinu tvořilo patnáct dívek a patnáct chlapců, kteří studovali střední nebo vysokou školu a byli aktivními členy souboru lidových tanců po dobu od dvou do patnácti let. Motivací jim byl kolektiv, potlesk divákủ, ale i zlepšení fyzické kondice a radost $\mathrm{z}$ tance. Kontrolní skupinu tvořilo patnáct dívek a patnáct chlapců ve věku osmnáct až dvacet let, kteří byli studenty jedné maturitní tř́dy gymnázia. V současné době jsou studenty různých vysokých škol, např. fakult pedagogických, právnických, lékařských, př́rodovědných, filosofických, ale také technických a ekonomických oborů. Tito respondenti nikdy organizovaně netancovali.

\section{Výzkumné metody}

V tomto výzkumu se jednalo o pedagogický experiment. K výzkumnému šetření jsme použili:

Brace test - standardizovaný speciální motorický test (Iowa Brace test, Čepička, 1999), který hodnotí schopnost učit se novým pohybovým dovednostem. Jde o test pohybového nadání. Testování respondentů jsme provedli v záŕí 2007 v gymnastickém sále gymnázia v Uherském Hradišti. Vzhledem k tomu, že tento test neměl být opakován, výstupní šetření u obou skupin jsme provedli až po čtrnácti měsících, tedy v listopadu 2008. Výsledky byly zpracovány pomocí statistických metod.

Cílem osobnostní ankety bylo zjistit osobní anamnézu testovaných - věk, pohlaví, vzdělání, jak dlouho a proč tancují, zda se chtějí tanci dále věnovat. Na základě prostudované cizojazyčné literatury jsme vytvořili nestandardizovaný test pohybové kreativity, $\mathrm{v}$ němž jsme $\mathrm{k}$ jednoznačným pohybovým tvarům přiřadili bodové hodnoty. Nejprve jsme respondenty nechali poslechnout 16 taktů hudby, na kterou následně improvizovali. Hudba byla při vstupním i výstupním šetření stejná. Byla rovněž stejná pro respon- 
denty experimentální skupiny i pro respondenty kontrolní skupiny. Hodnocení Brace testu i testu pohybové kreativity prováděly dvě osoby nezávisle na sobě.

Probandi byli seznámeni s projektem a po instruktáži vyplnili osobnostní anketu. U experimentální i u kontrolní skupiny jsme provedli vstupní šetření prostřednictvím Brace testu a testu pohybové kreativity. Výstupní šetření jsme opakovaně provedli u experimentální i kontrolní skupiny po čtrnácti měsících.

Brace test provádíme v malých skupinách, nebot pro něj není povolen žádný nácvik. Probandy nejdříve poučíme, že si nesmějí cviky zkoušet. Potom vybraná osoba předvádí jednotlivé cviky a probandi je postupně opakují. Test obsahuje 10 vybraných cviků. Každý proband má pouze dva pokusy a je hodnocen podle úspěšnosti (tab. 1). Proband může získat maximálně dvacet bodů.

Tabulka 1: Bodové hodnocení výsledků Brace testu

\begin{tabular}{|l|c|}
\hline splněno & body \\
\hline splněno na první pokus & 2 \\
\hline splněno na druhý pokus & 1 \\
\hline nesplněno & 0 \\
\hline
\end{tabular}

Test pohybové kreativity. Na základě prostudované cizojazyčné literatury jsme vytvořili nestandardizovanou baterii testu pohybové kreativity. Testovaným osobám nejdříve pustíme 16 taktů hudby a následně necháme testované osoby bez instrukcí improvizovat na vybranou hudbu. Probandy jsme testovali jednotlivě, bez prŕitomnosti ostatních. Při výběru hudby jsme se snažili zvolit takovou, která by nebyla ani v rychlém tempu, ani v pomalém tempu. Vhodně zvolená hudba je velmi důležitá, nebở může značně ovlivnit inspiraci testovaných osob. Není vhodné použít hudbu vokální, ani hudbu v aranžmá sólového nástroje. K pohybovým pózám a pohybům jsme přiřadili body od nuly do dvou. Jedná se o šest pohybových póz a pohybů:

1. Provedení statické pózy na začátku i na konci improvizace, provedení pózy jen na začátku nebo na konci improvizace, neprovedení žádné pózy.

2. Pohyb celým tělem včetně hlavy, pohyb dolními i horními končetinami, pohyb pouze $\mathrm{v}$ dolních končetinách.

3. Pohyb v prostoru trojrozměrném (vpřed a vzad, vpravo a vlevo, vzhůru a dolů), dvojrozměrném (vpřed a vzad, vpravo a vlevo) nebo jednorozměrném (vpřed a vzad).

4. Pohyb se stř́iáním pravidelného i nepravidelného rytmu hudby, pohyb jen v pravidelném rytmu hudby, pohyb v nesouladu s hudbou.

5. Provedení dvou a více rotací o třistašedesát stupňů, provedení pouze jedné rotace o třistašedesát stupňů, neprovedení žádné rotace.

6. Provedení jakýchkoliv dvou a více skoků, provedení jednoho skoku, neprovedení žádného skoku.

Každý proband má pouze jeden pokus a hodnocen je podle úspěšnosti (tab. 2). Proband může získat maximálně dvanáct bodů. 
Tabulka 2: Bodové hodnocení výsledků testu pohybové kreativity

\begin{tabular}{|c|c|c|c|c|c|c|}
\hline body & póza & pohyb těla & prostor & rytmus & rotace & skoky \\
\hline 2 & $\begin{array}{c}\text { na začátku i } \\
\text { na konci }\end{array}$ & $\begin{array}{c}\text { pohyb celým } \\
\text { tělem }\end{array}$ & trojrozměrný & $\begin{array}{c}\text { stř́dání } \\
\text { pravidelného } \\
\text { i nepravidelného } \\
\text { rytmu }\end{array}$ & dvě a více & dva a více \\
\hline 1 & $\begin{array}{c}\text { pouze } \\
\text { na začátku } \\
\text { nebo na konci }\end{array}$ & $\begin{array}{c}\text { pohyb horních i } \\
\text { dolních } \\
\text { končetin }\end{array}$ & dvojrozměrný & $\begin{array}{c}\text { pravidelný } \\
\text { rytmus podle } \\
\text { hudby }\end{array}$ & jedna & jeden \\
\hline 0 & neprovedeno & $\begin{array}{c}\text { pohyb pouze } \\
\text { dolních } \\
\text { končetin }\end{array}$ & jednorozměrný & $\begin{array}{c}\text { v nesouladu } \\
\text { s hudbou }\end{array}$ & neprovedeno & neprovedeno \\
\hline
\end{tabular}

Podle předběžných výsledků jsme předpokládali, že experimentální skupina bude vykazovat lepší výsledky než skupina kontrolní.

\section{VÝSLEDKY}

\section{Brace test}

Podle zjištěných výsledků vykazovala v Brace testu ES lepších výsledků než skupina kontrolní. Průměr dívek v ES činil 14,13 bodů a průměr chlapců 13,87. Při komparaci chlapců a dívek v experimentální skupině dosahovaly lepších výsledků dívky. Celkově dosáhla skupina v prvním testování hodnoty 14 bodů. Ve druhém testování průměr dívek dosáhl hodnotu 15,87, tedy dívky se zlepšily více jak o 1 bod. Průměr chlapců ve druhém testování byl 15,67, zlepšili se tedy skoro o dva body. V každém testování dosahovaly dívky lepších hodnot než chlapci. Celkově dosáhla skupina ve druhém testování průměr 15,77 bodu.

V KS bylo dosaženo podstatně nižších hodnot. Při vstupním testování dosáhl průměr dívek 11,13 bodů a průměr chlapců 13,33. Chlapci tedy dosahovali na počátku pedagogického experimentu vyšších hodnot než dívky. Celkově dosáhla skupina hodnoty 12,23 bodů. Při druhém měření byl průměr chlapců 13,73 a průměr dívek 11,13 bodů. Chlapci tedy opět dosahovali lepších výsledků než dívky. Celkově tedy dosáhla skupina hodnoty 12,43 bodu. U této skupiny bylo dosaženo malého zlepšení (tab. 3, obr. 1).

U obou měření jsme zjistili, že ES dosahuje lepších výsledků než KS (tab. 4). Při statistickém porovnání výsledků dvou skupin jsme porovnali výsledky obou skupin na $0,05 \%$ hladině významnosti a zjistili jsme, že oba tyto výsledky se liší velmi málo (vstupní šetření $z=1,959996$, druhé měření $z=1,959964$ ). Hodnoty ukázaly, že mezi oběma skupinami neexistuje žádná statistická významnost.

$Z$ hlediska věcné významnosti jsme zjistili, že v některých př́padech dosahuje tato významnost hodnoty více jak 0,8 , tedy že efekt věcné významnosti je velký ( 1 př́pad u prvního měření a 3 případy u druhého měření), hodnoty více jak 0,5 - tedy efekt věcné významnosti je střední (1 prrípad u prvního testování) a ostatní výsledky byly v oblasti malého efektu.

Tabulka 3: Brace test - výsledky měření u jednotlivých skupin

\begin{tabular}{|l|l|c|c|c|c|}
\hline BRACE TEST & & $\overline{\mathbf{x}}-1$. testování & $\mathrm{s}$ & $\overline{\mathrm{x}}$ - 2. testování & $\mathrm{s}$ \\
\hline \multirow{2}{*}{$\begin{array}{l}\text { experimentální } \\
\text { skupina }\end{array}$} & děvčata & 14,13 & 3,14 & 15,87 & 2,63 \\
\cline { 2 - 6 } & chlapci & 13,87 & 2,42 & 15,67 & 1,78 \\
\hline \multirow{2}{*}{ kontrolní skupina } & děvčata & 11,13 & 3,72 & 11,13 & 3,5 \\
\cline { 2 - 6 } & chlapci & 13,33 & 2,39 & 13,73 & 2,86 \\
\hline
\end{tabular}


Tabulka 4: Brace test - porovnání skupin ES a KS

\begin{tabular}{|l|c|c|c|c|}
\hline BRACE TEST & $\overline{\mathrm{x}}-1$. testování & $\mathrm{s}$ & $\overline{\mathrm{x}}-2$. testování & $\mathrm{s}$ \\
\hline $\begin{array}{l}\text { experimentální } \\
\text { skupina }\end{array}$ & 14,00 & 2,8 & 15,77 & 2,25 \\
\hline $\begin{array}{l}\text { kontrolní } \\
\text { skupina }\end{array}$ & 12,23 & 3,31 & 12,43 & 3,45 \\
\hline
\end{tabular}

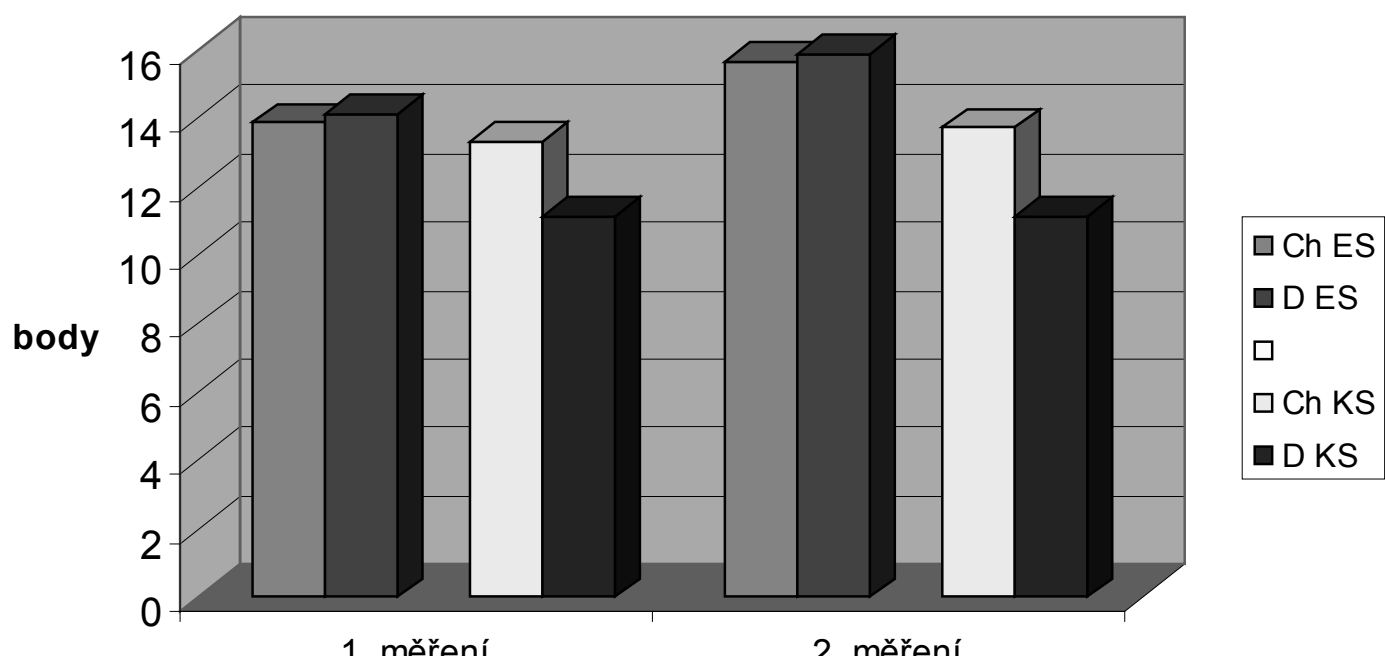

\section{měře ní}

Obr. 1: Brace test - výsledky jednotlivých skupin

\section{Test pohybové kreativity}

V tomto testu vykazovala ES lepší výsledky než KS. Při komparaci testovaných chlapců a dívek v ES vykazovali lepší výsledky tentokrát chlapci (7,47 - 1. měření, 9,33 - 2. měření). Nejlepšího výsledku dosáhla TO 24 - 12 bodů (z 12 možných) v prvním testování, ve druhém testování dosáhla nejlepšího výsledku TO 9 - 12 bodů (z 12 možných). Dívky v ES dosahovaly průměrného výsledku při prvním měření 6,47 a ve druhém měření 8,13 (tab. 5, obr. 2). Nejlepšího výsledku dosáhla TO 10 - 10 bodů (z 12 možných) v prvním měření a ve druhém měření dosáhla nejlepšího výsledku TO 6 - 12 bodů (z 12 možných). Celkově dosáhla ES v prvním měření hodnotu 6,97 bodu a ve druhém 8,73.

KS vykazovala lepší výsledky ve druhém testování. Při komparaci chlapců a dívek v kontrolní skupině podle výsledků vykazují lepší výsledky dívky (3,33 - 1. měření, 3,6 - 2. měření).

Celkově byl průměr 3,27 u prvního měření a 3,47 u druhého měření.

Pokud srovnáme $\mathrm{v}$ testu pohybové kreativity probandy experimentální a kontrolní skupiny, probandi v experimentální skupině vykazují výrazně lepší výsledky než probandi ve skupině kontrolní. Všichni probandi v experimentální skupině se pohybují v nadprůměru, zatímco všichni probandi v kontrolní skupině se pohybují pod průměrem (tab. 6, obr. 3).

Při statistickém porovnání obou skupin jsme porovnali výsledky na $0,05 \%$ hladině významnosti a zjistili jsme, že oba tyto výsledky se neliší (vstupní i výstupní šetření má hodnotu z = 1,959994). Hodnoty ukázaly, že mezi oběma skupinami neexistuje žádná statistická významnost.

$Z$ hlediska věcné významnosti jsme zjistili, že ve všech př́padech dosahuje tato významnost hodnoty více než 0,8 , tedy že efekt věcné významnosti je velký, a to jak ve vstupním, tak ve výstupním měření. 
Tabulka 5: Test pohybové kreativity - výsledky jednotlivých skupin

\begin{tabular}{|l|l|c|c|c|c|}
\hline $\begin{array}{l}\text { TEST POHYBOVÉ } \\
\text { KREATIVITY }\end{array}$ & & $\overline{\mathrm{x}}$ - 1. testování & $\mathrm{s}$ & $\overline{\mathrm{x}}$ - 2. testování & $\mathrm{s}$ \\
\hline \multirow{2}{*}{$\begin{array}{l}\text { experimentální } \\
\text { skupina }\end{array}$} & děvčata & 6,47 & 1,82 & 8,13 & 2,5 \\
\cline { 2 - 6 } & chlapci & 7,47 & 2,25 & 9,33 & 1,85 \\
\hline \multirow{2}{*}{ kontrolní skupina } & děvčata & 3,33 & 0,79 & 3,60 & 1,2 \\
\cline { 2 - 6 } & chlapci & 3,20 & 0,4 & 3,33 & 0,79 \\
\hline
\end{tabular}

Tabulka 6: Test pohybové kreativity - porovnání skupin

\begin{tabular}{|l|c|c|c|c|}
\hline $\begin{array}{l}\text { TEST POHYBOVÉ } \\
\text { KREATIVITY }\end{array}$ & $\overline{\mathrm{x}}$ - 1. testování & $\mathrm{s}$ & $\overline{\mathrm{x}}$-2. testování & $\mathrm{s}$ \\
\hline $\begin{array}{l}\text { experimentální } \\
\text { skupina }\end{array}$ & 6,97 & 2,11 & 8,73 & 2,28 \\
\hline $\begin{array}{l}\text { kontrolní } \\
\text { skupina }\end{array}$ & 3,27 & 0,63 & 3,47 & 1,02 \\
\hline
\end{tabular}

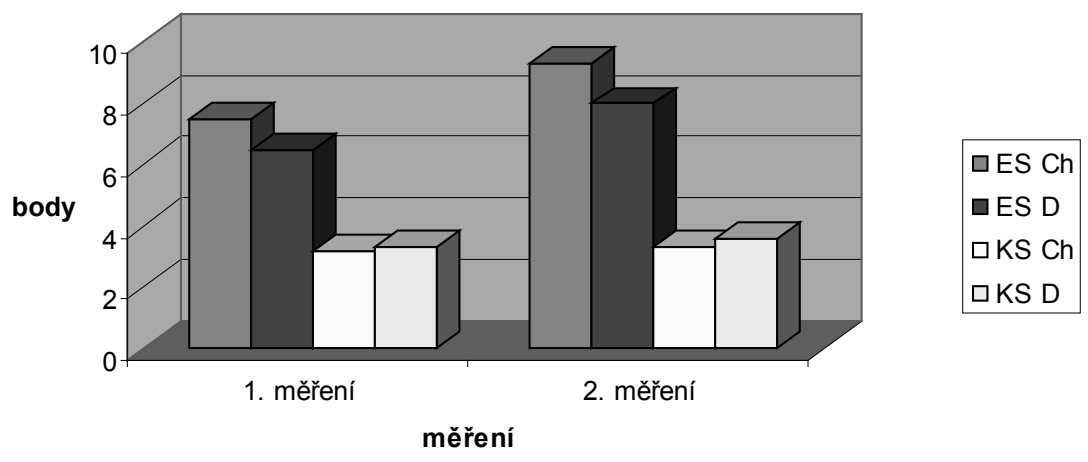

obr. 2: Test pohybové kreativity výsledky u jednotlivých skupin

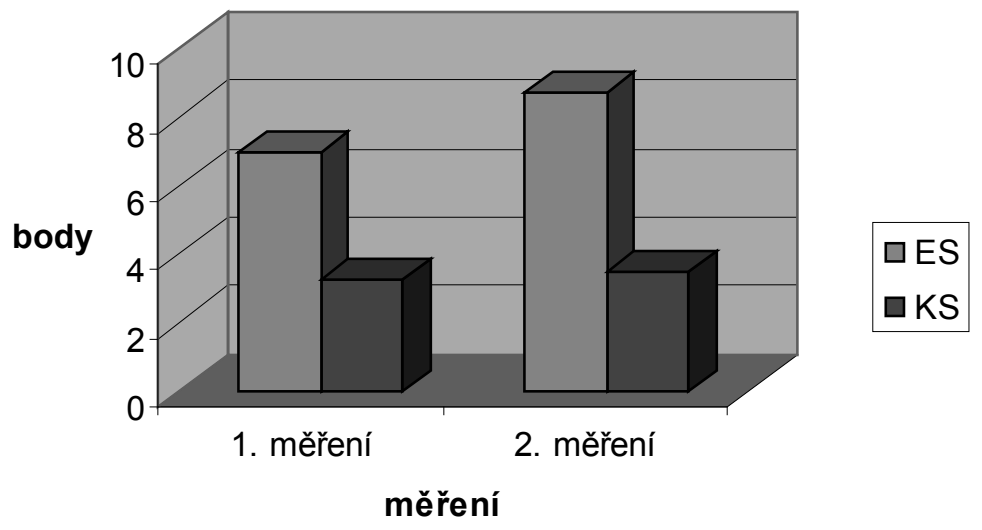

Obr. 3: Výsledky testu pohybové kreativity u ES a KS 
Při výzkumném šetření jsme mohli u adolescentů, kteří tancují, pozorovat $\mathrm{z}$ osobnostních korelátů zejména společenskost s výrazným projevem citové stránky a určitou úroveň inteligence. U adolescentů netančících se ovšem objevili i probandi, kteří byli spíše uzavření bez výrazného projevu citové stránky. Poněvadž kontrolní soubor tvořili probandi z gymnázia, jejich inteligence byla rovněž na určité úrovni. Dalším pozorovaným osobnostním korelátem u obou zkoumaných souborů byla citová vyrovnanost a labilita. Většina probandů spadala do skupiny citově vyrovnaných, jen pět probandů se jevilo labilními. Dalším osobnostním korelátem pozorovaným u testovaných adolescentů byl temperament. Všichni probandi v experimentální skupině byli velmi temperamentní, na rozdíl od kontrolní skupiny.

Experimentální skupina v Brace testu v prvním testování dosáhla lepších výsledků než skupina kontrolní, což mohlo být ovlivněno tím, že probandi z experimentální skupiny měli za sebou již zkušenosti z tanečních souborů. Délka tanečních zkušeností se u jednotlivých probandů lišila. U žádného probanda nedošlo ke zhoršení v celkovém počtu bodů v Brace testu při komparaci prvního a druhého testování. Šest dívek se dostalo na bodovou hranici, kterou vykazoval profesionální tanečník. Jednalo se o dívky, které provozovaly nejenom taneční pohybovou aktivitu, ale věnovaly se ještě další sportovní aktivitě. U chlapců na tuto bodovou hranici dosáhli čtyři probandi.

V testu pohybové kreativity vykazovala v prvním testování experimentální skupina lepší výsledky než skupina kontrolní. Při komparaci testovaných chlapců a dívek v experimentální skupině vykazovali lepší výsledky tentokrát chlapci, ale to není ve světě tance žádné překvapení, nebot většina vynikajících světových tanečníků a choreografư jsou výhradně muži. Když se podíváme do tanečních kroužků a na základní umělecké školy, najdeme naprostou převahu dívek, ale pokud budeme sledovat profesionální „špičku ledovce“, tak s ženským elementem se zde setkáme velmi málo. Nejlepší výsledky vykazovala TO 10, která vystudovala muzikálové herectví na Janáčkově akademii múzických umění v Brně a v současné době je sólistkou Městských divadel v Brně. V souboru byla nejlepší tanečnicí a také sólovou zpěvačkou. Pozici výborné tanečnice si držela ještě předtím, než začala studovat obor muzikálové herectví. U této dívky zájem o lidový tanec odstartoval její profesní růst, který ji přivedl na dráhu muzikálové herečky. Z chlapců dosáhl nejlepších výsledků proband TO 24, kterého můžeme považovat za nejvšestrannějšího tanečníka. I když se pohybuje pouze v oblasti lidového tance, je schopen zatancovat jakýkoliv druh tance a bude vypadat vždy velmi elegantně a s velmi přirozeným projevem. Oba probandi nejenže perfektně zvládají tance technicky, ale nechybí jim ani výraz a procítění každého pohybu. Jejich pohybový projev byl vždy velmi kultivovaný a pro oko diváka ladný a harmonický. Oba probandi navíc vykazovali velkou schopnost zapamatovat si velké množství choreografií po velmi dlouhou dobu. Nechyběla jim ani dávka empatie a byli rovněž velmi trpělivými učiteli. Dokázali vždy velmi přesně a s citlivým př́stupem k druhým pomoci při nácviku nejen jednotlivých kroků a motivů, ale také celých choreografií.

V testu pohybové kreativity dosáhli probandi kontrolního souboru lepší výsledky ve druhém testování. V prvním testování vykazovala nejlepší výsledky TO 12 , která v hodinách tělesné výchovy vždy patřila k „motorům“ celé skupiny. Dívka pěstovala výkonnostní sport. Celkově však byla kontrolní skupina v prvním měření podprůměrná. Při komparaci chlapců a dívek v kontrolní skupině dosáhly lepších výsledků dívky.

Při porovnání obou testovaných skupin můžeme usuzovat, že kreativitu adolescentů mohou výrazně ovlivňovat nejen osobnostní koreláty, ale významnou měrou i kognitivní koreláty, které posouvají adolescenty v rozvoji kreativity.

\section{ZÁVĚRY}

$\mathrm{V}$ rámci našeho výzkumu jsme se pokusili vědecky ověřit a zdokumentovat vliv tance na pohybovou kreativitu u adolescentů. Na základě prostudované literatury jsme dospěli k názoru, že znalost a dovednost tanečních technik posouvá člověka v pohybové kreativitě. Na základě výsledků můžeme konstatovat, že tanec výraznou měrou ovlivňuje nejen kreativitu adolescenta, ale i jeho motivační složku osobnosti a výrazně se podílí na kvalitě jeho života.

Adolescenti, kteří se pravidelně věnují pohybovým aktivitám nad rámec své povinné školní docházky dosahují vždy lepších výsledků než adolescenti nesportující. Tanec je však rozvíjí nejen po stránce fyzic- 
ké, nýbrž i po stránce duševní, a přispívá také k rozvoji jejich kreativity. Kreativita je u adolescentů vždy důležitým prvkem rozvoje osobnosti. Pohyb mladého člověka kultivuje a tance mu přinášejí řadu kladných podnětů, které jej mohou ovlivnit na celý život.

\section{LITERATURA}

BEAN, R. Jak rozvíjet tvořivost dítěte. Praha: Portál, 1995. ISBN 80-7178-035-9

BLAHUTKOVÁ, M., ŘEHULKA, E., DVOŘÁKOVÁ, Š. Pohyb a duševní zdraví. Brno: Paido, 2005. ISBN 80-7315-108-1

BLAHUTKOVÁ, M., DVOŘÁKOVÁ, Š. Pohyb a duševní zdraví ve vztahu ke kvalitě života. In Sport a kvalita života, sborník článků a abstrakt z mezinárodní konference konané 10.-11. 11. 2005 v Brně. Brno: MU FSpS, 2005. ISBN 80-210-3863-2

CARTER, P., RUSSELL, K. Trénink paměti kreativity. Brno: Computer Press, 2003. ISBN 80-7226-704-3

CARTER, P., RUSSELL, K. Trénink paměti kreativity 2. Brno: Computer Press, 2004. ISBN 80-251-0327-7

CLEGG B., BIRCH, P. Kreativita. Brno: CP Books, 2005. ISBN 80-251-0549-0

COHEN, J. (1994). The earth is round, p < 0,5. In: American Psychologist, 49, s. 997-1003.

DACEY J. S., LENNON K.H. Kreativita. Praha: Grada Publishing, 2000. ISBN 80-7169-903-9

DOČKAL, V. Zaměřeno na talenty. Praha: Lidové noviny, 2005. ISBN 80-7106-840-3

GORDONOVÁ, C. Jste výjimeční? Praha: Fortuna Print, 2003. ISBN 80-7321-094-0

KIRST, W., DIEKMEYER U. Trénink tvořivosti. Praha: Portál, 1998. ISBN 80-7178-227-0

KÖNIGOVÁ, M. Tvořivost. Praha: Prada, 2007. ISBN 978-80-247-1652-7

MACEK, P. Adolescence. Praha: Portál, 1999. ISBN 80-7178-348-X

MACEK, P., LACINOVÁ, L. Vztahy v dospívání. Brno: Barrister \& Principal, 2006. ISBN 80-7364-034-1

MAISEL, E. Trénink kreativity. Praha: Portál, 2002. ISBN 80-7178-677-2

MORGENROTH, J. Dance Improvisations. Pittsburgh: University of Pittsburgh Press, 1987. ISBN 0-8229-3550-3

NAKONEČNÝ, M. Psychologie osobnosti. Praha: Academia, 2007. ISBN 978-80-200-1680-5

PAYNEOVÁ, H. Kreativní pohyb a tanec. Praha: Portál, 1999. ISBN 80-7178-213-0

PETROVÁ, A. Tvořivost v teorii a praxi. Praha: Vodnář, 1999. ISBN 80-86226-05-0 